\title{
Liquidated Damages in California
}

\section{SCOPE}

\section{$\mathrm{T}$}

HIS paper deals with the law of liquidated damages in Cali-' fornia, discussing the basis of the remedy and its elements.

In addition to these matters of substantive law the procedural problems affecting liquidated damages will be considered. The sections of the Civil Code now in effect in California have been incorporated into the statutory law of several of the other Western states ${ }^{\mathbf{1}}$ and while the law of these states is not considered specifically, much that is contained herein will be applicable to jurisdictions other than California.

\section{BASIS OF LIQUIDATED DAMAGES}

Originally the only remedy available in case of breach of contract was a legal action for damages, but in many cases such relief was entirely inadequate. Chancery met this situation by evolving the remedy of specific performance; the common-law courts by developing liquidated damages. ${ }^{2}$

Both specific performance and liquidated damages were, in their origin, exceptional remedies applicable only where the normal remedy of legal damages failed to give adequate relief, and this exceptional nature has been retained by each ever since. ${ }^{3}$ But while the lack of an adequate remedy at law is the basis for both specific performance and liquidated damages, various other elements must be present in order to secure relief by either of these remedies.

\section{ELEMENTS OF LIQUIDATED DAMAGES}

The California law of liquidated damages was codified in 1872 by sections 1670 and 1671 of the Civil Code." They provide:

1 Cf. Cal. Civ. Code, $\$ \S 1670-1671$ with Rev. Code Montana (1907) $\$ \S 5054$, 5055; Rev. Laws Oklahoma (1910) $\$ \S 975,976$; Comp. Laws North Dakota (1913) $\$ \$ 5925,5926$; Comp. Laws South Dakota (1913) Civil Code $\$ \S 1274$, 1275 .

2 Glock v. Howard (1898) 123 Cal. 1, 7, 55 Pac. 713, 69 Am. St. Rep. 17, 43 L. R. A. 199.

${ }^{3}$ Ibid., p. 8 ff.

4 These sections have not been changed since their adoption. 
\$1670. Contract fixing damages, void. Every contract by which the amount of damage to be paid or other compensation to be made, for a breach of an obligation, is determined in anticipation thereof, is to that extent void, except as expressly provided in the next section.

\$1671. Exception. The parties to a contract may agree therein upon an amount which shall be presumed to be the amount of damage sustained by a breach thereof, when, from the nature of the case, it would be impracticable or extremely difficult to fix the actual damage.

But before considering the elements involved in these sections of the Code we should notice the effect of their adoption in 1872 upon the law of liquidated damages as it then existed.

\section{Effect of Adoption of Code of 1872}

Whether these code sections have modified the law of liquidated damages is a mooted question. It has been answered by the District Court of Appeal on several occasions ; 5 but the second and third appellate districts have expressed different views on the subject. The former has referred to the Code sections in one case as modifying ${ }^{b}$ and in another case as narrowing the general law of liquidated damages. The latter, on the other hand, has declared that the sections establish no new principles of law in this state. ${ }^{8}$

While these sections may not have materially changed the law in California, yet they did have a definite effect. The law, which had formerly been obscure in several particulars and which had become involved in apparently conflicting adjudications, was classified and settled. In the first place, a uniform wording of the rule was provided in place of the varying phraseology used by the earlier cases. Secondly, the codification removed the conflict which had previously existed as to the importance to be given the particular words used by the parties in their contract. Thirdly, greater emphasis was placed upon the facts of each case instead of upon the mere form of the contract. Finally, a presumption was raised which had not previously existed that contracts in which damages are estimated in advance are void.

These results of the codification will be discussed in detail.

5 Los Angeles Olive Growers' Ass'n. v. Pacific S. Co. (1914) 24 Cal. App. 95, 99, 140 Pac. 295; Weinreich Estate Co. v. A. J. Johnson Co. (1915) 28 Cal. App. 144, 150, 151 Pac. 667; Anaheim Citrus Fruit Association v. Yeoman (1921) 34 Cal. App. 798, 799, 197 Pac. 959. Petition to have case heard and determined in Supreme Court denied May 16, 1921.

${ }^{B}$ Los Angeles Olive Growers' Ass'n. v. Pacific S. Co., supra, n. 5.

7 Anaheim Citrus Fruit Association v. Yeoman, supra, n. 5.

8 Weinreich Estate Co. v. A. J. Johnston Co., supra, n. 5. 


\section{a. Effect upon Statement of the Rule of Liquidated Damages.}

Section 1671 of the Civil Code provides that liquidated damages will be allowed only where it is "impracticable or extremely diffcult to fix the actual damages." This exact phraseology is not found in any of the earlier cases. In two cases the court used the phrase "wholly uncertain and incapable of estimation otherwise than by mere conjectures." " In a third case the language of the court was "difficult, if not impracticable to estimate the amount of damages"; $;$ "while in a fourth case the phraseology was "uncertain and not measureable by any exact pecuniary standard." 11 In combining these various expressions of the same idea into one phrase the Code accomplished a real service.

\section{b. Effect upon importance of words used by the parties.}

The second result of the codification was its effect upon the importance to be given the language used by the parties in their contract.

In Streeter v. Rush ${ }^{12}$ in 1864 the court laid considerable emphasis on the terms of the agreement and considered the use of the phrase "liquidated damages" or the word "penalty" as practically controlling in determining the nature of the stipulated sum. This was in direct conflict with the earlier case of People v. Love $^{13}$ which placed very little weight upon the particular phraseology used in the agreement. Neither the argument of counsel nor the opinion of the court in the Streeter case refers to the earlier decision. The Code, however, seems to have settled the conflict and the doctrine of the Love case has been uniformly followed since 1872; and the wording of the contract has been considered merely as one of the circumstances among all the others which the court must consider. ${ }^{14}$

\section{c. Nature of each case emphasized instead of Form of Agreement.}

The third result of the codification was to direct the attention of the court to the nature of each case rather than to the form of the agreement.

Cal. Steam Nav. Co. v. Wright (1856) 6 Cal. 258, 263; Streeter v. Rush (1864) 25 Cal. 67, 71.

10 Fisk v. Fowler (1858) 10 Cal. 512, 517.

11 People v. Love (1862) 19 Cal. 676, 682.

12 Supra, n. 9.

is Supra, n. 11.

14 See infra, p. 14, for a complete discussion. 
Section 1671 of the Civil Code permits liquidated damages where "from the nature of the case it would be impracticable or extremely difficult to fix the actual damages" and, as will later be developed, ${ }^{15}$ the California courts in interpreting this clause have looked at the facts of each case. ${ }^{16}$ This was not always done before 1872. In Nash v. Hermosilla, ${ }^{17}$ for example, action was brought for liquidated damages upon the breach of a building contract. In the course of its decision the court says:

"The cases upon the subject are numerous and it is difficult to deduce from them any certain and definite rule. In fact, transactions of individuals are so various that the circumstances in many cases are so peculiar that no certain rule can be adopted for all cases."

But the court says further:

"But from the decisions the following results seem to be substantially correct:

1. When the party stipulates to pay a stated sum for a given period of time during the continuance of the failure, then the damages are to be considered as liquidated.

2. When the agreement is not to carry on trade at a particular place; not to run a stage-coach on a particular road; not to publish a rival newspaper; not to run a rival steamer on a particular route. In all these cases, the sum stated must be taken as liquidated damages.

3. When the party stipulates to marry no other person; to convey land or pay a named sum, the price of the land having been received by him, the damages are liquidated.

4. When a named sum is to be paid for every acre of land ploughed up contrary to agreement; when a stated sum is to be paid for each article not delivered, the damages must be considered as liquidated.

5. When the party stipulates to erect a building in a particular manner, within a given time, and upon failure to pay a named sum, it must be considered in the nature of a penalty." By the application of the last of these rules, liquidated damages were refused in the Nash case. The court recognized, however, that it might be difficult to estimate actual damages, stating:

"In building contracts, it may be difficult to say what amount of injury the plaintiff has sustained by reason of the non-com-

15 Infra, p. 20.

16 Nakagawa v. Okamoto (1913) 164 Cal. 718, 723, 130 Pac. 707; Pogue v. Kaweah Power and Water Co. (1903) 138 Cal. 664, 668, 72 Pac. 144; Dyer Bros. G. W. Iron Works v. Central Iron Works (1920) 182 Cal. 588; 189 Pac. 445; Anaheim Citrus Fruit Association v. Yeoman (1921) 34 Cal. App. Dec. 798. 800, 197 Pac. 959.

in (1858) 9 Cal. 584, 588. 
pletion of the building within the exact time stated. And yet this difficulty, in ascertaining the amount of the injury occasioned by the delay, has not induced the Courts, in such cases, to consider the sum as liquidated damages."

Just as in the Streeter case, ${ }^{18}$ the court has laid especial importance upon the words used by the parties; so in the Nash case the form of the agreements was emphasized rather than the intent of the parties, the nature of the obligation or the facts of the case. Since the enactment of the Code, the impracticability or difficulty of ascertaining actual damages is the test; liquidated damages are now granted in building contracts the same as in other types of contract. ${ }^{19}$ The court looks at the nature of each case, not at the form of the agreement. ${ }^{20}$

\section{d. Presumption of illegality.}

The fourth change brought about by the Code was the creation of the presumption of illegality raised by section 1670 of the Civil Code. This section provides:

"Contract fixing damages, void. Every contract by which the amount of damage to be paid, or other compensation to be made, for a breach of an obligation, is determined in anticipation thereof, is to that extent void, except as expressly provided in the next section."

According to this section, all contracts in which damages are estimated in advance are presumed to be void. In order to secure liquidated damages it is necessary to plead and prove facts to take the case out of the operation of section 1670 and place it within the exception of $1671 .{ }^{21}$ This principle has been reiterated repeatedly in California. ${ }^{22}$ Before 1872 there was no such presumption, nor is it mentioned in any of the early cases. ${ }^{23}$

Bearing in mind these four results of the adoption of sections

18 Streeter v. Rush, supra, n. 9.

19 Consolidated Lumber Co. v. Los Angeles (1917) 33 Cal. App. 698, $166 \mathrm{Pac}$. 385. See infra, p. 28, for a more detailed discussion of buidling contracts.

${ }_{20}$ See infra, pp. 17-19, for a complete discussion of the five rules of the Nash case.

21 Cal. Civ. Code.

22 Long Beach etc. Dist. v. Dodge (1902) 135 Cal. 401, 405, 67 Pac. 499 ; Dyer Bros. G. W. Iron Works v. Central Iron Works (1920) 182 Cal. 588, 189 Pac. 445; Sherman v. Gray (1909) 11 Cal. App. 348, 351, 104 Pac. 1004 ; Los Angeles Olive Growers' Association v. Pacific S. Co. (1914) 24 Cal. App. 95, 99, 140 Pac. 295; Thomas v. Anthony (1916) 30 Cal. App. 217, 220, 157 Pac. 823; McInerney v. Mack (1917) 34 Cal. App. 153, 157, 166 Pac. 867; Rez v. Summers (1917) 34 Cal. App. 527, 529, 168 Pac. 156.

${ }^{23}$ In the dissenting opinion of Streeter v. Rush, supra, n. 9 , it is said: "When it is doubtful on the face of the instrument whether the sum men- 
1670 and 1671, we may next consider the elements involved in an action for liquidated damages under the Code.

\section{Elements of Liquidated Damages under the Code}

In applying section 1670 and 1671 of the Civil Code two different questions are presented. The first of these is whether the parties intended the sum in question to be liquidated damages or a penalty. The second is whether, from the nature of the case, it is impracticable or extremely difficult to fix actual damages. Both of these elements must concur in order that the remedy may be available. ${ }^{24}$

\section{a. Intention.}

The intention of the parties must be ascertained in each case from the entire instrument, its scope, purpose and subject-matter. The result of the breach and the reasonableness of the sum agreed upon must be considered, together with the language used by the parties. The agreement must be construed in light of all the circumstances under which it was executed. It can then be determined whether, under the facts of the particular case, the stipulated sum is enforceable as liquidated damages or is void as a penalty. ${ }^{25}$

i. Legal Intent, Not Actual Intent-It must be borne in mind that the word "intent" as used in the legal sense in the subject of liquidated damages may be entirely different from the actual intention present in the lay minds which met to form the contract, and "Under certain circumstances the law will impute an intention to the parties not derivable from the ordinary sense of the

tioned was intended to be stipulated damages or a penalty to cover actual damages, the Courts hold it to be the latter." This was the general rule in other jurisdictions, 8 R. C. L., p. 564, para. 114, and n. 19, but it was never applied in California. It was applied in Los Angeles v. Shafer (1921) 35 Cal. App. Dec. 605, 609, by the minority opinion, the majority agreeing in the result reached on different grounds.

24 In some decisions the court first looks at one of these elements, in other decisions at the other. If it is determined that one of the necessary elements is lacking then the other need not be considered. Greenleaf $v$. Stockton C. H. \& A. Works (1889) 78 Cal. 606, 609, 21 Pac. 369. A public corporation is subject to sections 1670 and 1671 in the same manner as a private individual or corporation. City of Los Angeles v. Shafer (1921) 35 Cal. App. Dec. 605, 609.

25 Dyer Bros. Golden West Iron Works v. Central Iron Works (1920) 182 Cal. 588, 189 Pac. 445; Nakagawa v. Okamoto (1913) 164 Cal. 718, 723, 130 Pac. 707; Anahcim Citrus Fruit Ass'n. v. Yeoman (1921) 34 Cal. App. Dec. 798, 799, 197 Pac. 959; Stark v. Shemada (1921) 34 Cal. App. Dec. 867, 868. A statutory undertaking must bc construed in the light of the statute and if the statute contemplates the recovery of actual damages such must be held to be the intention of the parties. Los Angeles v. Shafer (1921) 35 Cal. App. Dec. 605,610 . 
words. In many cases it has been held that the parties could not have meant what they apparently said." ${ }^{26}$

It is, therefore, of utmost importance that a clear, definite test of intention be laid down by the courts.

ii. Reasonableness of Stipulated Sum-In Dyer Bros. v Central Iron Works ${ }^{2 \tau}$ the California Supreme Court finally defined the legal intention which governs and thus in a large measure clarified the California rule. Was there "an actual intent to prescribe a penalty, that is, an intent to determine and define the liability in the case of breach of contract without any reference to the actual damage likely to be sustained" 28 ... "to furnish a club to be used to prevent a violation of the contract" ${ }^{29}$ or, on the other hand, was there an intent "to estimate a just compensation for the loss sustained in the event of a failure to comply with the agreement"? ${ }^{30}$

The important element in determining intent, according to the Dyer case, is the reasonableness of the stipulated sum. If there is an intent to fix liability "without any reference to the actual damage to be sustained," the stipulated sum is a penalty, but if there is an intent "to establish a just compensation for the loss sustained," it is enforceable as liquidated damages.

The reasonableness of the stipulated sum or the hardship or unfairness of enforcing the agreed amount as stipulated damages, was not considered of importance in the earlier cases where the use of the words "liquidated damages" or "penalty" was held almost conclusive, regardless of how unfortunate or ill-advised the agreement proved to be. ${ }^{31}$ Later cases modified this attitude, however, and the rule laying special emphasis upon the reasonableness of the agreed sum is now well established in California.

iii. Words Used-The California courts thus look to substance rather than to form; little attention is paid to the particular words used. As we have heretofore indicated, this is a complete change of front. ${ }^{32}$ In some of the earlier cases considerable importance

${ }_{26}$ People v. C. P. R. R. Co. (1888) 76 Cal. 29, 36, 18 Pac. 90. Of similar import is Muldoon v. Lynch (1885) 66 Cal. 536, 540, 6 Pac. 417. In Anaheim Citrus Fruit Association v. Yeoman, supra, n. 25 , the court states at p. 799 : “itrus Fruit Association of the parties is not the main fact to be ascertained in such a case, but it is rather that the court shall be enabled to find out as to whether, under all the circumstances, the parties have made a contract which is, under the law, enforceable." The court here refers to the "actual intention" of the parties.

$2 \tau$ (1920) 182 Cal. 588, 189 Pac. 445.

28 Ibid., p. 592.

29 Ibid., p. 592.

30 Ibid., p. 593.

31 Streeter v. Rush (1864) 25 Cal. 67.

32 Supra, p. 10. 
was placed upon the wording of the agreement and special emphasis was laid upon the use of the words "penalty," "forfeiture," or "liquidated damages."

Streeter $v$. Rush ${ }^{33}$ may be taken as an example of this attitude. The court therein stated : ${ }^{34}$

"In construing the instrument, resort must be had to the signification of the terms employed by the parties, and to the rules of law, in view of which the parties are presumed to have contracted. If the parties agree upon the payment of a certain sum, whether in terms as a penal sum or not, if it can be plainly understood that the gross sum was intended as a security for the payment of a less sum, it will be held as a penalty; and it is also a general rule that if the parties agree that the sum shall be paid as liquidated damages, the Court will so regard it, unless it clearly appears that it was intended merely as a security for the payment of damages that might be considered liquidated and certain in amount.

Where the contract contains both the terms "penalty," and "liquidated damages," as applied to the gross sum to be paid, or equivalent terms, or where it contains neither of those terms, the Court will ascertain the intention of the parties from the whole instrument as it would in case of any other agreement. (Sedg. Dam. 417 to 422 .) If the damages for the performance or non-performance of the act stipulated to be done or not to be done by the party agreeing to pay the gross sum can be ascertained with certainty, or have been agreed upon between the parties, then, as in the case where the parties have denominated it a penalty, the Court will consider it as a security; but if they are "wholly uncertain, and incapable of estimation, otherwise than by mere conjecture," as was said in Williams v. Dakin, 22 Wend. 201, the gross sum will be regarded as liquidated damages. This is a rule by which to ascertain the intention of parties in cases of doubt, and not to enlarge or limit the intention, when expressed or clearly ascertainable without its aid. Courts are not authorized to put a different construction upon a contract from what the parties intended it should bear; nor are they warranted in adding to it a further term, or in striking therefrom a term the parties have employed; nor are they justified in attempting to modify or reform a contract under the vague notion of relieving a party from the hardships of an agreement into which he has willingly and knowingly entered. Parties are more competent to make their own bargains than Courts are to make bargains for them."

Of course, form did not completely, control. Even in the earlier decisions the language of the contract was not the final test. In

33 (1864) 25 Cal. 67.

34 Ibid., p. 71 . 
People v. Love ${ }^{35}$ the legality of a bail bond was involved. It was claimed that the use of the word "penal" in the recognizance made the sum specified a penalty and precluded enforcement of the contract. The court, however, answered this contention by stating : $: 36$

"Although it has been sometimes said that where the parties to an agreement use the word "penalty," it can under no circumstances be held to be liquidated damages, while on the contrary the use of the term "liquidated damages," in the most determined manner, can have no effect where other considerations require that it should be treated as a penalty, certainly there never was any good reason for attributing so different an efficacy to the use of these terms. Mr. Parsons, in his work on contracts, ( 2 vol. 434) states the rule on this point to be: 'that the action of the Court shall not be defined and determined by the terms which the parties have seen fit to apply to the sum fixed upon. Though they call it a penalty, or give it a name at all, it will be treated as liquidated damages; that is, it will be recognized and enforced as the measure of damages if, from the nature of the agreement and the surrounding circumstances, and in reason and justice, it ought to be." "

This is the present attitude of the courts. In Anaheim Citrus Fruit Association v. Yeoman ${ }^{37}$ the courts said : ${ }^{38}$

"More recent authorities including decisions of our own Supreme Court have rescinded from the view that the language of the parties in characterizing the damages fixed is of controlling effect or of any great force in determining the legal effect to be given the contracts ..... Under this rule the affairs of the persons concerned, as expressed in their contract, become items only to be considered in the aggregate of evidence."

Calling the stipulated sum a penalty instead of liquidated damages does not change its nature. ${ }^{30}$ Contracts containing the word "penalty" or "forfeiture" have been held to be proper subjects for liquidated damages ${ }^{40}$ and contracts speaking only of liquidated

35 (1862) 19 Cal. 676.

36 Ibid., p. 682 .

37 (1921) 34 Cal. App. Dec. 798, 197 Pac. 959.

38 Ibid., p. 789.

39 Green v. Frahm (1917) 176 Cal. 259, 262, 168 Pac. 114. In Pogue v. Kaweah Water Co. (1903) 138 Cal. 664, 72 Pac. 144, the court said at p. 667 : “. It matters not what particular terms are used in the contract; even if the thing to be done be called a 'penalty' or 'liquidated damages,' or given no name at all, it will be treated according to the evident intent of the parties and the subject matter of the contract."

to Dyer Bros. Golden West Iron Works v. Central Iron Works (1920) 182 Cal. 588, 198 Pac. 445; Stark v. Shemada (1921) 34 Cal. App. Dec. 867. 
damages have been held to be penalties. ${ }^{41}$ At most, the particular word used gives rise to a rebuttable presumption but to no more. ${ }^{42}$

But when the parties, besides using the word "liquidated damages," go further and declare in their contract that it is difficult to estimate actual damages, a stronger situation is presented and a different rule applies. It has been held that "such a declaration tends strongly to establish the facts required by the statute to exist and further tends to control the question as to whether the provision is one of liquidated damages or for a penalty, where the contract appears on its face to be one allowed by the terms of section $1671 . "$ 43

While liquidated damages are granted although the word "penalty" or the word "forfeiture" is used in the agreement, a careful conveyancer would take no chances and would avoid the use of any expressions that would serve as circumstantial evidence to tend to vitiate that part of the agreement. The Japanese are warned by an old proverb "Never tie your slipper in your neighbor's melon patch nor arrange your hair in his orchard." Likewise the modern lawyer should be warned never to use the word "forfeiture" nor speak of a penalty when he is drawing a contract for liquidated damages.

\section{b. Difficulty or impracticability in determining actual damages.}

In addition to an intention of the parties to provide for liquidated damages, it is also necessary that a second element be present. The nature of the case must be such that it is impracticable or extremely difficult to ascertain actual damages.

In Nash v. Hermosilla, ${ }^{44}$ as has been previously pointed out, ${ }^{45}$ five rules were laid down for determining whether liquidated damages should be granted. Each case that arose was to be placed in one of these stereotyped classifications regardless of its particular facts, the hardships involved, or fairness and good faith.

The first of these rules was:

"When the party stipulates to pay a stated sum for a given period of time during the continuance of the failure, then the damages are to be considered as liquidated."

41 Pacific Factor Co. v. Adler (1891) 90 Cal. 110, 27 Pac. 36, 25 Am. St. Rep. 102; Easton v. Cressey (1893) 100 Cal. 75, 34 Pac. 622; Long Beach v. Dodge (1902) 135 Cal. 401, 67 Pac. 499; Sherman v. Gray (1909) 11 Cal. App. 348, 104 Pac. 1004.

12 Stark v. Shemada (1921) 34 Cal. App. Dec. 867, 868.

13 Consolidated Lumber Co. v. Los Angeles (19i7) 33 Cal. App. 698, 700,166 Pac. 385.

44 (1858) 9 Cal. 584.

45 Supra, p. 11. 
This rule has been definitely discarded. Liquidated damages have been refused where the facts were within this principle whenever it was neither difficult nor impracticable to determine actual damages. ${ }^{46}$

The second rule reads:

"When the agreement is not to carry on trade at a particular piace; not to run a stage coach on a particular road; not to publish a rival newspaper; not to run a rival steamer on a particular route, in all these cases the sum stated must be taken as liquidated damages."

This rule is still observed and liquidated damages are uniformly granted in such contracts. ${ }^{47}$ Actual damages are considered so absolutely uncertain that the plaintiff need only prove the execution of the contract and its breach in order to recover the stipulated damages. ${ }^{48}$

The third rule:

"When the party stipulates to marry no other person, to convey land or pay a named sum, the price of the land having been received by him, the damages are liquidated."

No cases involving these facts have arisen since the Code was adopted. If we judge by the verdicts reached in some breach of promise cases, damages at law are more than adequate, but if we try to reconcile the various results attained in such suits we must agree that marriage contracts offer a promising field for the extensive use of liquidated damages. As the blushing maiden says "Yes" to her fervent suitor she should softly speak of $\$ 10,000$ liquidated damages in case of his unfaithfulness. It will require considerable tact, but it will save all the publicity and annoyance of a long-drawn-out jury trial.

The second group of cases under this rule would not, as a general rule, present a proper situation for a remedy. The usual

16 Patent Brick Co. v. Moore (1888) 75 Cal. 205. If it were difficult or impracticable to fix the actual damages liquidated damages would be granted. Consolidated Lumber Co. v. Los Angeles (1917) 33 Cal. App. 698, 166 Pac. 385.

47 Cal. Steam Nav. Co. v. Wright (1856) 6 Cal. 258; Streeter v. Rush (1864) 25 Cal. 67; Potter v. Ahrens (1896) 110 Cal. 674, 43 Pac. 388; Shafer v. Sloan (1906) 3 Cal. App. 335, 85 Pac. 162. See also Nash v. Hermosilla (1858) 9 Cal. 585, 588; Lightner v. Menzel (1868) 35 Cal. 45்; Franz v. Bieler (1899) 126 Cal. 176, 56 Pac. 249, 58 Pac. 466; Akers v. Rappe (1916) 30 Cal. App. 290, 158 Pac. 129; Johnston v. Blanchard (1911) 16 Cal. App. 321, 116 Pac. 973. But liquidated damages are not granted where a business is sold at invoice price under a contract providing for a forfeiture of deposit if full purchase price is not paid. Biescar v. Pratt (1906) 4 Cal. App. 288.

48 Shafer v. Sloan (1906) 3 Cal. App. 335, 338, 85 Pac. 162; Potter v. Ahrens (1896) 110 Cal. 674, 680, 43 Pac. 388. 
liquidated damages for such a breach would be adequate. ${ }^{49}$ It is possible, however, that a situation might arise in which liquidated damages should be granted. Where the securing of a particular piece of property is a small but essential part of a much larger scheme and where success or failure of a huge enterprise will depend upon its possession, it is conceivable that liquidated damages could well be proper.

The fourth rule:

"When a named sum is to be paid for each acre of land ploughed up contrary to agreement; when a stated sum is to be paid for each article not delivered, the damages must be considered as liquidated."

No cases have arisen involving the first part of the rule and it seems doubtful if any ever will. The facts given suggest a contract in the alternative, not one involving liquidated damages. ${ }^{50}$ A large number of cases, however, have been decided involving the second part of the rule, and liquidated damages have been refused, even though a stated sum was to be paid for each article not delivered. In each such case legal damages provided adequate relief. $^{51}$ In other cases, however, where the legal remedy was inadequate, liquidated damages were granted. ${ }^{52}$

The fifth rule:

"When the party stipulates to erect a building in a particular manner within a given time and upon failure to pay a named sum, it must be considered in the nature of a penalty."

This was the holding which governed the decision in the Nash case and, as has been previously pointed out, it is no longer law in this state. $^{.53}$

Another of the well-established rules which the earlier cases emphasize covers those cases wherein the same sum was payable in case of breach of a number of covenants of varying degrees or in case of a breach of a part as well as the whole of a contract.

49 Cal. Civ. Code $\$ 3306$ "Breach of agreement to convey real property. The detriment caused by the breach of an agreement to convey an estate in real property is deemed to be the price paid, and the expenses properly incurred in examining the title and preparing the necessary papers, with interest thereon; but adding thereto, in case of bad faith, the difference between the price agreed to be paid and the value of the estate agreed to be conveyed at the time of the breach, and the expenses properly incurred in preparing to enter upon the land."

501 Sutherland: Damages (4th Ed.) \$282. I Sedgwick: Damages (9th Ed.) $\$ 421$. 2 Williston Contracts $(1920) \$ 781$.

51 Pacific Factor Co. v. Adler (1891) 90 Cal. 110, 27 Pac. 36.

52 Anaheim Citrus Fruit Ass'n. v. Yeoman (1921) 34 Cal. App. Dec. 798, 799, 197 Pac. 959. Petition to have case heard and determined in Supreme Court denied May 16, 1921.

53 Supra, p. 11. 
The earlier authorities usually held that such a situation established that a penalty was intended, regardless of the facts of the case. The courts looked at the agreement as of the time of its execution and not as of the time of the breach. If by any chance the stipulated damages could become payable upon the happening of various contingencies, it would be held to provide for a penalty, even though the facts of the case showed that there was an absolute breach of every covenant for which there was no adequate remedy. ${ }^{54}$

The later decisions, on the other hand, have looked at the nature of each case as required by the Code and have applied the principle of just compensation. In several instances liquidated damages have been granted where the stipulated sum was payable in the event of a breach of any one of a large number of covenants, some of which were of minor importance and others of which were vital to the contract, and where the same sum was payable for a total as for a partial breach. ${ }^{55}$ With one exception-Los Angeles Olive Growers' Association v. Pacific Surety Company ${ }^{58}$ - the rule was not discussed or mentioned, but in the Olive Growers' Association case the rule was specifically repudiated. The case went up on an appeal from an order sustaining a demurrer to a complaint. The court therein stated:57

"By the terms of the contract Tajiri covenanted to do a number of things varying in degree of importance. He was to furnish bedding and food for the men; keep one general foreman who spoke English, and a boy who spoke English with every twenty men; pick the fruit clean; not thrash the trees with clubs; and not allow any one connected with the Japanese camp to furnish intoxicating liquors to any one of plaintiff's white help. For a failure to comply with any of these provisions, it was stipulated in the contract that the amount of damage sustained by reason of such noncompliance should be the sum of one thousand dollars. Says Mr. Pomeroy in his work on Equity Jurisprudence, section 443; 'Where an agreement contains

54 People v. C. P. R. R. Co. (1888) 76 Cal. 29, 36, 18 Pac. 90; Nash v. Hermosilla (1858) 9 Cal. 585, 588.

55 Los Angeles Olive Growers' Association v. Pacific S. Company (1914) 24 Cal. App. 95, 140 Pac. 295; Escondido Oil Co. v. Glaser (1904) 144 Cal. 494, 77 Pac. 1040. In sales of the good will of an established business with an agreement not to compete with the purchaser for a certain number of years, a lump sum is often provided as liquidated damage in case of breach of the agreement and the same sum is payable in case the competition occurs during the first year or the last year of the agreement. Franz v. Bieler (1899) 126 Cal. 176, 56 Pac. 249, 58 Pac. 466; Potter v. Ahrens (1896) 110 Cal. 674, 43 Pac. 388. See also Akers v. Rappe (1916) 30 Cal. App. 290, 158 Pac. 129.

${ }_{60}$ Supra, n. 55.

57 Ibid, p. 98. 
provisions for the performance or nonperformance of several acts of different degrees of importance, and then a certain sum is stipulated to be paid upon a violation of any or of all of such provisions, and the sum will be in some instances too large and in others too small a compensation for the injury thereby occasioned, that sum is to be treated as a penalty, and not as liquidated damages.' Applying this rule, respondent insists that the sum of one thousand dollars damages stipulated in the contract must be regarded as a penalty. Looking to the code, however, we find the rule modified by section 1670 of the Civil Code, as follows: 'Every contract by which the amount of damage to be paid, or other compensation to be made, for a breach of an obligation, is determined in anticipation thereof, is to that extent void, except as expressly provided in the next section.' The next section, 1671 of the Civil Code, provides: 'The parties to a contract may agree therein upon an amount which shall be presumed to be the amount of damages sustained by a breach thereof, when, from the nature of the case, it would be impracticable or extremely difficult to fix the actual damage.' It thus appears that an agreement whereby the parties to a contract fix the amount of damages for a breach of its obligations in anticipation thereof may be enforced as a valid contract where, from the nature of the case, it would be impracticable or extremely difficult to fix the actual damage."

Under the old system of stereotyped classifications in all cases of liquidated damages, the demurrer would have been good, but applying the California rule of reasonable damage and looking at the particular breach involved, a cause of action was stated.

In Vath v. Hallett, ${ }^{58}$ the District Court of Appeal of the Third District laid down the rule that where a contract provided for the same sum as stipulated damages for a complete violation of its terms, as for a partial violation, it must be held to be a penalty. A petition to have the case heard in the Supreme Court was denied, but the Supreme Court, after approving the decision on another ground, $^{59}$ stated $^{80}$ that it was not satisfied with the correctness of the views expressed by the District Court of Appeal on the point in question and withheld an expression of any opinion upon it. While it might appear that the granting or denying of liquidated damages in a case where the same damages are stipulated for total or partial breach is still an open question as far as the Supreme Court is concerned, the argument of the Appellate Court in the Olive

68 (1916) 31 Cal. App. 290, 160 Pac. 1065.

${ }^{59}$ That the complaint did not state facts showing a substantial breach.

60 Ibid, p. 295. 
Growers' case, however, is sound and convincing and will undoubtedly be followed by the Supreme Court.

\section{c. Summary of Elements Involved.}

We have so far seen that in some contracts the nature of the case is such that it would be impracticable or extremely difficult to fix the actual damages. In such situations the parties may provide for liquidated damages if they so desire by estimating " a just compensation for the loss sustained in case of a failure to comply with the agreement." It makes little difference what words the parties use in their contract. The court looks at the substance of the agreement rather than at form, and if it is impracticable or extremely difficult to fix actual damages and if the parties have estimated in advance a reasonable sum to be paid in case of breach, their agreement will be enforced by the court. Each particular case must be considered upon its own facts. That attitude of our courts in this respect can best be determined by a brief consideration of the cases in which they have applied these code rules.

\section{Particular Situations}

These cases may be grouped as follows: First, those cases which involve concerted action among individuals engaged in the same business; the second, those in which a stipulated sum was payable, so much per unit in case of a breach; and third, those which involve realty.

\section{a. Concerted Action Among Individuals Engaged In Same Business}

Nakagawa v. Ikamoto, ${ }^{61}$ Dyer Brothers Golden West Iron Works v. Central Iron Works, ${ }^{62}$ and Anaheim Citrus Fruit Association v. Yeoman ${ }^{63}$ each involves a group of individuals in the same line of business who have contracted together for concerted action along some particular line. In these cases each of the individuals had agreed that in case of breaching the common agreement he would pay to the others, either as individuals or as a corporate entity, a certain stipulated sum as damages. In the first of the cases this sum was held to be a penalty and illegal, in the other two cases it was held to be liquidated damages and enforceable.

In the Nakagawa case, a large number of Japanese farmers

61 (1913) 164 Cal. 718, 130 Pac. 707.

62 (1920) 182 Cal. 588, 189 Pac. 455.

63 (1921) 34 Cal. App. Dec. 798, 197 Pac. 959. 
engaged in raising vegetables to be sold in the Los Angeles markets were members of an unincorporated association known as the Japanese Farmers' Association which existed without any articles of association, by-laws or agreement. Most of the members of this Association were doing business at the Third Street market in Los Angeles. In June, 1909, they left this location and moved to the Ninth Street market. It would seem that some of the members of the Association must have approached Hashimuro Togo $0^{64}$ and must have asked him to draw up for them the necessary legal papers in order to protect themselves in true American fashion. And Hashimuro Togo, out of the fulness of his knowledge of correspondence school law, must have worked long and late in giving birth to the documents that resulted. The agreement was as follows: $:$ :5

"We, the undersigned, since moved to the Ninth Street new market, we must pray for the success of the said market, and it became necessary to provide for the expansion of the said market. Therefore, each of us agrees to protect new market, and furthermore, in order to show their good faith, not to be persuaded by the Third Street old market under any inducement, each of us hercby agree to put up five hundred dollars in promissory notes, and at the same time it is agreed that in case of violation of the agreement, the note at once become due; and it is understood and agreed that there would be no objection for the members of the association to attach the property.

"In witness whereof, each of us do hereby sign our names."

To this agreement the following preamble appeared in the minutes. ${ }^{66}$

"Since Japanese farmers, Chinese and white farmers moved to the Ninth Street new market the old market is in very lonesome condition. They feel especially in the scarcity of vegetables. They bought up Japanese farmers with money, or bought up farmers by inducing Chinese with money, and attempted to buy with several hundred dollars. We, the Farmers' Association, tried to prevent it, and also in order to prevent it we provided that each member of the association to give a five hundred dollar note payable one day after date, and after each signed an agreement we took the note. The agreement and the note are as follows:"

Some of the members became dissatisfied, left the Ninth Street market and reopened at the old stand. Suit was brought upon the

61 Vid. Wallace Irwin: Letters of a Japanese Schoolboy.

65 At page 720 of the opinion.

66 At page 721 of the opinion. 
notes and the court was called upon to determine whether, from the nature of the case, liquidated damages would be proper. The court stated:

"To our minds it is impossible to read the so-called agreement in the light of the circumstances that we have set forth without being convinced that the provisions as to the notes were intended purely by way of penalty or forfeiture, and without any reference to the question of damage. The sole design of these provisions was apparently to furnish a club to be used to prevent any person signing the agreement from returning to the Third Street Market, by making him liable to a penalty or fine of five hundred dollars if he so did, absolutely irrespective of any question of damage. This object is plainly avowed in the preamble on the minutes of the Japanese Farmers' Association, which we have hereinbefore set forth. It is furthermore expressly avowed, in effect, in the agreement itself, and there is nothing in the circumstances shown by the evidence to detract in the slightest degree from the effect of the language used in the writing."

Dyer Brothers' Golden West Iron Works v. Central Iron Works ${ }^{68}$ - the second of the group-involved a contract made by a number of structural steel and iron manufacturers of San Francisco for the mutual protection and advancement of their business interests and conditions. The court describes their agreement as follows : ${ }^{69}$

"Among the objects and purposes sought to be attained by the contract were the promotion of settlements of industrial disputes between the parties to the contract, as employers, and their employees, by conciliation and arbitration, and the effecting of a more thorough organization of employers with the view to improving the conditions of the industry in which the several respective employers were engaged. To be more precise, the contract recites that the parties thereto were desirous of protecting themselves against various and sundry demands of their employees; that the parties were unable to resist, settle or arbitrate said demands singly and severally without great loss to themselves and injury to their business; that, in the event of any parties withdrawing from the agreement and ceasing to act in concert with the remaining parties, great damage and loss would result which might not be recoverable under. the law of damages and which damage would be impracticable of ascertainment or proof under the rules of evidence. After providing for certain uniform regulations and restrictions

${ }^{67}$ At page 723 of the opinion.

${ }^{68}$ Supra, n. 62.

${ }^{69}$ Ibid., p. 589. 
to govern the conduct of the parties to the contract and for an executive committee to represent them in specified dealings and negotiations, the contract requires that each party pay into a common fund a sum of money in cash, or promissory notes given in lieu thereof, the amount thereof to be determined by the gross annual business of the party making such payment. This fund was to be kept intact until the termination of the agreement, by lapse of time or otherwise, and then be distributed among the parties who had kept the covenants and conditions of the contract in the proportion which the amount of their respective payments into the fund bore to the whole of said fund. All of the parties elected to make the required payments by means of promissory notes. The complaint alleges failure on the part of the defendants to observe and abide by the terms of the agreement, thereby causing great loss to plaintiffs and necessitating the termination of the agreement, and prays that all the parties to said contract be directed to pay into the common fund contemplated by the contract the respective sums represented by their several promissory notes and that such common fund be distributed among the plantiffs, or those determined by the court to be entitled to participate in the distribution under the terms of the contract."

A general demurrer to the complaint was sustained on the ground that the sums represented by the promissory notes were penalties and not liquidated damages. The court, after discussing the cases on the subject, said : ${ }^{70}$

"The agreement in question provides a complicated arrangement for the purpose of meeting various conditions incapable of being satisfactorily dealt with by individual action, and sets forth at length the peculiar facts surrounding the subject-matter of the contract. The securing and maintaining of united action in certain contingencies by the parties thereto was the gist of the contract, and from the terms of the contract it is apparent that the parties thereto considered that any independent action in regard to the matters within the scope of the contract was likely to produce serious losses and defeat the aims and purposes contemplated by the parties. The sums to be paid for a noncompliance in this regard were not uniform amounts arbitrarily determined, but were to be based upon the gross business transacted by the respective parties, evidently upon the theory that the loss to those continuing to observe the terms of the contract depended in a considerable measure upon the volume of business of the party ceasing to act in unison with the remaining parties. The contract is thus clearly distinguishable from that class of contracts in which an arbitrary sum is to be paid for each day during which the violation of the con-

to Ibid., p. 590. 
tract continues (Patent Brick Co. v. Moore, 75 Cal. 205; Hansen v. Vallejo Electric etc., Co., 59 Cal. Dec. 357.) Nor can it be said of the provisions under consideration, as was said in the case of Nakagawa v. Ikamoto, supra, that 'the sole design of these provisions was apparently to furnish a club to be used to prevent' a violation of the contract ... Looking to the entire agreement, its scope, purpose, and subject-matter, and considering the result of a breach and the reasonableness of the sums agreed to be paid therefor, it is clear that there was an intent to estimate a just compensation for the loss sustainable in the event of a failure to comply with the agreement."

The judgment of the lower court was reversed.

The Dyer Brothers case involved an agreement by employers for collective bargaining with their employees, while the third case of the group-Anaheim Citrus Fruit Association v. Yeoman ${ }^{71}$-involved an agreement by producers for the collective bargaining of their products. The material facts of this case, as stated by the District Court of Appeal, are as follows: ${ }^{22}$

"In the record presented it is shown that the plantiff was, at all times material to the controversy, a corporation organized for the purpose of enabling its members to jointly conduct the operation of harvesting and marketing citrus fruits grown upon land owned by such members. The underlying plan of the organization was co-operative, and no persons were eligible to membership except those who produced citrus fruit which they desired to market. The by-laws which were subscribed by the stockholders provided that the corporation should have the sole and exclusive right to pick, grade, pack, market and sell the citrus fruit raised by the members on the land described in the certificates of stock-in brief, gave to the association the exclusive right to manage and control the harvesting and marketing of crops of the several members. The condition expressed in the by-laws under which the alleged cause of action arose was that which required of a stockholder who failed to permit the association to market his fruit, while remaining a member, that he pay the sum of fifty cents per box for every box of fruit otherwise sold or consigned. In the year 1919 the defendant, who was then a member of the association, plantiff, marketed 568 boxes of oranges through agencies outside of the association, and refused to pay the stipulated fifty cents per box to the plaintiff. This action was thereafter brought.

Appellant insists that the judgment rendered in this case cannot be upheld for several reasons, chief of which is that 
the stipulation expressed in the by-laws, providing for the payment of fifty cents per box by each stockholder who should violate the agreement, is void and of no effect; this because, as it is argued, the condition imposed a penalty which the law does not permit to be recovered."

The court, however, affirmed the judgment for liquidated damages, stating $:^{73}$

"Irrespective of this expression in the contract, we think that the facts and circumstances shown in evidence all support the plantiff's contention that recovery should be sustained for the amount fixed by the by-laws of the association. The association was organized for the purpose of the better handling of citrus fruits through the co-operative and joint effort of its members. From the nature of the organization and the statement of its purposes as found in its articles and by-laws, it can be fairly and reasonably inferred that by the co-operation of its members, mutual advantages would accrue to all through greater economy in handling and shipping and the securing of more advantageous marketing facilities. These results would be dependent directly upon the performance by the members of their agreemert to deliver their fruit into the hands of the association for the purposes declared. Defendant sought to show at the trial that the damage which would accrue to the association by reason of any of its members failing or refusing to market their fruit through the association could be easily and exactly ascertained, and that such damage would consist wholly of a proportionate amount of overhead operating cost. By the line of questioning pursued, it was made clear that the association would suffer an actual monetary loss by reason of the failure of defendant to deliver his fruit at the association packing house for market, as he had agreed to do, but in the very nature of the case we do not think that such damage should be the only damage considered to have been suffered by the plaintiff. Other elements have already been suggested. The existence and life of the association itself depended upon its being furnished fruit to dispose of in the public market. A reduction in the amount of fruit so handled would not only tend to increase the overhead cost to the non-transgressing members, but, we may assume, to some extent affect the prestige and standing of the association as a marketing concern. The argument would be the same, regardless of the quantity of fruit which might have been delivered by the defendant, whether it composed but a small fractional part or one-half or more of the entire product designed to be marketed by the plantiff agency. Enough has been said, we think, to show that the case falls within the class as to which the law permits damages to be

73 Ibid, p. 800. 
liquidated by contract in advance of their occurrence. (3) It follows as a necessary conclusion that plaintiff was entitled to recover the exact amount fixed in its contract as the sum per box which defendant should pay by reason of his failure to market this fruit in the matter agreed."

The Japanese Vegetable Farmers of Los Angeles, the San Francisco Steel and Iron Manufacturers, and the Anaheim Orange Growers' cases all recognized the value of concerted action and cooperative effort. Each of these groups endeavored to provide some method of reimbursement in case one of their number proved unfaithful to the joint undertaking.

The agreement drawn up by the Japanese provided for a "penalty or fine," "absolutely irrespective of any question of damages," "a club to be used to prevent" a breach of the agreement. Such an arrangement could not be enforced.

The agreements drawn up by the Steel Manufacturers and the Orange Growers, on the other hand, contained none of the "big stick" characteristics which rendered the Japanese agreement illegal. In these agreements the Courts found "an intent to estimate a just compensation for the loss sustainable in the event of a failure to comply with the agreement." Liquidated damages were, therefore, granted in the last two cases and refused in the first.

These three situations emphasize the need of considering. each case upon its particular facts instead of attempting to state broad, general rules. The next group of cases is even more diversified and emphasizes this to a still greater extent.

\section{b. Stipulated Sum Payable So Much Per Unit In Case Of Breach.}

The second group of cases involves those in which a stipulated sum is payable for each day's failure to complete certain work according to the contract, or to pay a stipulated sum per unit for each unit which the defendant fails to deliver in accordance with his agreement.

Several of the cases arising under this classification were decided by the California courts entirely upon procedural matters and must, therefore, be differentiated from those cases which were decided upon the merits. As examples of the former category are Long Beach District v. Dodge ${ }^{74}$ and Patent Brick Company v. Moore. ${ }^{75}$

74 (1902) 135 Cal. 401, 67 Pac. 499.

75 (1888) 75 Cal. 205. 
In Long Beach District v. Dodge a building contract contained a $\$ 10$ a day stipulated damage clause. The plaintiff introduced evidence showing the impracticability and the difficulty of establishing actual damages and the court awarded the stipulated sum. The Supreme Court, however, reversed the judgment, holding ${ }^{i 6}$ that, as there was no issue presented in the pleadings as to the impracticability or extreme difficulty of proving actual damages, evidence to that effect was irrelevant and outside the issues. In Consolidated Lumber Company v. Los Angeles, ${ }^{77}$ on the other hand, similar facts were properly pleaded and proved and a liquidated damage clause of $\$ 50$ a day in a building contract was sustained.

Patent Brick Company v. Moore ${ }^{78}$ was a case of a like character, in which the court considered a building contract with $\$ 100$ per day stipulated damage clause. Plaintiff did not plead nor did the court find that in the nature of the case it was impracticable or extremely difficult to $f x$ actual damages. The judgment for liquidated damages was therefore reversed.

These cases involving only procedual questions must not be confused with those which were determined upon the merits of the facts. The latter will next be considered.

In Pacific Factor Company v. Adler ${ }^{29}$ there was an agreement to pay three cents per bag for each bag which defendant refused to deliver to plaintiff to be sold by plaintiff as defendant's agent. The Supreme Court held :so

"In the present case we think when the plaintiff rested, the 'nature of the case,' as presented by the terms of the contract, and its breach as admitted by the answer, was such that the court could decide as a fact that it was neither extremely difficult nor impracticable to fix the actual damage sustained by the plantiff by reason of the defendant's breach of the contract. The refusal of the defendant to deliver the bags may have deprived the plaintiff of its commissions for selling, and under certain circumstances it may have suffered other damage, but we can imagine no case where any damage could have resulted to the plaintiff by reason of a breach of this contract, and which the plaintiff would have been entitled to recover in a court of law, where it could be said that it was impracticable or extremely difficult to fix the actual damage."

\footnotetext{
zo 135 Cal. 401 , at p. 405.

77 (1917) 33 Cal. App. 698, 166 Pac. 385.

78 Supra, n. 75.

79 (1891) 90 Cal. 110, 27 Pac. 36, 25 Am. St. Rep. 102.

80 Ibid., p. 120.
} 
This case should be compared with the case of Anaheim Citrus Fruit Association v. Yeoman ${ }^{81}$ which has previously been discussed. $^{82}$ In that case defendant agreed to pay fifty cents per box for each box of oranges delivered other than in accordance with the contract. The District Court of Appeal found that liquidated damages had been properly proved and sustained the judgment. The court in its opinion stated : $: 3$

"The existence and life of the association itself depended upon its being furnished fruit to dispose of in the public market. A reduction in the amount of fruit so handled would not only tend to increase the overhead cost to the non-transgressing members, but, we may assume, to some extent affect the prestige and standing of the association as a marketing concern. The argument would be the same, regardless of the quantity of fruit which might have been delivered by the defendant, whether it composed but a small fractional part or one-half or more of the entire product designed to be marketed by the plaintiff agency. Enough has been said, we think, to follow that the case falls within the class as to which the law permits damages to be liquidated by contract in advance of their occurrence."

In the Pacific Factor case there was an ordinary contract of agency and damages were easily ascertained. In the Anaheim Fruit Growers' case a co-operative marketing association was involved which handled the products of its members only and the existence of which depended upon the performance of the contracts in question. From the nature of the one case, damages could be easily ascertained; from the nature of the other case they were impracticable or extremely difficult to ascertain.

Muldoon v. Lynch ${ }^{84}$ presents a more difficult situation. The plaintiffs and defendant executed a written contract by which plaintiffs were to furnish a marble tomb of Italian marble for the grave of defendant's deceased husband. Defendant agreed to pay over $\$ 18,000$ for the tomb and the contract contained a clause providing for a "forfeiture of $\$ 10$ per day for each and every day beyond the stated time for completion." The monument was delivered two years late owing to the delays and difficulties of transportation. Plaintiff sued for the balance of almost $\$ 12,000$ due on the purchase price, while the defendant sought to set off the

81 (1921) 34 Cal. App. Dec. 798, 197 Pac. 959.

82 Supra, p. 27.

83 Ibid., p. 800.

84 (1885) 66 Cal. 536, 6 Pac. 417. 
sum of $\$ 10$ per day as liquidated damages, amounting in all to $\$ 7820.00$.

The court in the Muldoon case, in holding the agreement a penalty, laid especial emphasis, if it did not base its opinion, upon the use of the word "forfeiture" by the parties ${ }^{85}$ the influence of the earlier California cases which were decided before the adoption of the Code being very apparent in the opinion. If the delay had merely been for one or two days or a week or a month, it is doubtful whether the decision of the court would have been the same, for, as the court pointed out, ${ }^{80}$

"It might have been quite difficult for the defendant to show any damage of a pecuniary nature for the non-completion of the monument at the time specified thereon; its completion might have been of great comfort and consolation to her affectionate remembrance."

If a situation, however, was ever presented in which it was difficult or impracticable to estimate actual damages, it would be a situation such as is presented in the Muldoon case. At the same time, it would also appear that $\$ 10$ a day for each day's delay would be a reasonable amount upon an $\$ 18,000$ contract, thus combining the two elements necessary to secure liquidated damages.

While the reasoning of the court in this case cannot be approved, yet the result might be justified upon a different theory, the theory that the parties practically abandoned the contract due to the length of the delay. When the parties agreed upon $\$ 10$ a day as stipulated damages, it might be said that it was never contemplated by them that the delay would amount to two years. Such a delay almost amounts to an abandonment of the contract and liquidated damages for delay in performance beyond the time fixed for completion in the contract do not apply where the contract is abandoned.87 The intent of the parties was to fix damages for delay and not for abandonment.

The Muldoon case does not present the situation of an abandonment of a contract, but it might be said that the parties could never have contemplated that liquidated damages should apply to the extent of the delay involved. In other words, it might

85 Ibid., p. 539.

so Ibid., p. 540.

87 Bacigalupi v. Phoenix Building Co. (1910) 14 Cal. App. 632. This is the general rule. 8 R. C. L. p. 577 , paragraph 126, but cf. with Escondido Oil Etc. Co. v. Glaser (1904) $144 \mathrm{Cal}$. 494, $77 \mathrm{Pac}$. 1040, where there was an abandonment of the contract but where the rule was not considered. 
be contended that the delay was so great that it was a practical abandonment of the contract as far as a liquidated damage clause was concerned. Upon this theory the decision might be justified, but this justification rather strains the abandonment theory. The case is surely an extreme one and emphasizes the necessity for considering each case upon its own particular facts.

The Muldoon case should be compared with Allen v. Narver, ${ }^{88}$ which concerned a contract where defendant agreed to dig certain oil-wells upon a plaintiff's land on a royalty basis. The contract provided for the payment of $\$ 100$ per month for each month beyond the agreed date during which defendant failed to commence operation. The defendant sued for default for twenty months and recovered judgment for $\$ 2,000$. The amount sought in this case was considered fair and reasonable by the court, while in the Muldoon case it was held excessive and unjust. It is difficult to reconcile these two cases. If twenty months delay was not an abandonment of the contract in the one case, twenty-four months delay should not have been in the other. It is true that in the oil situation the landowner was deprived of the use of his land during the period in question and lost any possible advantage that the keeping of the contract might have developed, so that the stipulated sum might be considered in the nature of rent for the property instead of liquidated damages..$^{39}$ This distinction, however, does not seem sufficient to justify the difference in the two decisions.

\section{c. Contracts Involving Realty}

The third group of cases to be considered involves real estatesales and leases. In contracts for the sale of land the vendee may secure liquidated damages if the vendor refuses to convey, while in case of default by the vendee of his payments where time is of the essence, the vendor may retain all previous payments. As $\mathrm{Mr}$. Justice Henshaw said in Glock v. Howard, it does not matter whether the forfeited payments be considered liquidated damages or not-the vendor retains them in either case and the effect is the same. ${ }^{90}$

Ordinarily, in the case of a lease, default by the lessee in the

83 (1918) 178 Cal. 202, 172 Pac. 980.

89 The rent theory was advanced by the Supreme Court in McComber $:$ Kellerman (1912) 162 Cal. 749, 752, 124 Pac. 431 and in Allen v. Narver, supra, n. 88, at page 205.

9o Glock v. Howard (1898) 123 Cal. 1, 13 ff, 55 Pac. 713, 69 Am. St. Rep. 17, 43 I. R. A. 199. 
payment of rent or his breach of other terms of the contract will not entitle the lessor to liquidated damages.91 Particular facts, however, may be present which will bring the case within the provisions of section 1671 of the Civil Code. Oil-well digging or oil-land leasing contracts upon a royalty basis are the most common example of this situation. In such contracts, liquidated damages have been uniformly granted both in the shape of a lump sum or a specific sum per month during the continuance of the breach. ${ }^{92}$ Similarly, liquidated damages were awarded ${ }^{93}$ in an agreement to deliver a specific amount of water each year in consideration of the granting of certain land, rights of way, water rights, etc., where it was impracticable and extremely difficult to estimate actual damages. ${ }^{94}$

The oil-well cases present an interesting contrast to the situation found in Sherman v. Gray. ${ }^{95}$ Defendants agreed to remove the surplus sand from plaintiff's property and to level, grade and cover the land with clay. The contract contained a mutual stipulated damage clause providing for the payment of $\$ 100$ in case of any breach by either party. Defendant removed far more sand than was agreed upon and failed to level and grade the property or to put in the clay. When he was sued for damages, he sought to limit them to the stipulated sum. This the court refused to do, as the testimony of the case showed that it was a simple matter to ascertain actual damages. The case, therefore, came within section 1670 of the Code and the penalty clause had no effect upon the actual damages.

A sufficient number of cases have been considered upon their particular facts to show the attitude of the California courts whenever liquidated damages are involved. Our attention can now be turned to the adjective law involved. The particular remedy to be secured must first be considered, followed by a discussion

91 Jack v. Sinsheimer (1899) 125 Cal. 563, 58 Pac. 130; Green v. Frahm (1917) 176 Cal. 259, 168 Pac. 114; Knight v. Marks (1920) 183 Cal. 354, 191 Pac. 531 .

92 Escondido Oil Co. v. Glaser (1904) 144 Cal. 494, 77 Pac. 1040; Allen v. Narver (1918) 178 Cal. 202, 172 Pac. 980; McComber v. Kellerman (1912) 162 Cal. 749, 124 Pac. 431.

93 Pogue v. Kaweah Power Co. (1903) 138 Cal. 664, 72 Pac. 114.

94 In Meer v. Cerati (1921) $35 \mathrm{Ca}$. App. Dec. 631, 639, a cropping lease was under discussion and the court stated that liquidated damages might be applicable to such agreements, although in the particular case the court found that the parties had not intended to so provide.

95 (1909) 11 Cal. App. 348, 104 Pac. 1004. 
of the pleading problems which are present in a liquidated damage suit.

\section{THE REMEDY}

Generally liquidated damages are secured by an action at law for a money judgment, but occasionally equitable relief is necessary to secure an adequate remedy.

In Pogue v. Kaweah Power Company ${ }^{96}$ the defendant had agreed to convey to plaintiff certain easements and water rights in case he breached the contract. $\mathrm{He}$ failed to perform and the plaintiff sought specific performance of the liquidated damage clause. The court in granting the remedy pointed out:

"And in such a case there is evidently no difference between agreeing to pay a stipulated sum of money and agreeing to do some other act as to give a certain piece of property for failure to perform a contract with respect to which the damages resulting from the failure are uncertain and not susceptible of computation and compensation in an action for damages."

Dyer Brothers v. Central Iron Works ${ }^{97}$ is another example of the use of an equitable remedy to enforce liquidated damages. In this case the liquidated damages were in the form of promissory notes, one of which each of the parties to the agreement had sigued. These were placed in a common fund to be kept intact until the termination of the agreement, when the proceeds were to be distributed proportionately among the parties who kept the covenant.

The complaint alleged defendant's failure to abide by the terms of the agreement and prayed that all the parties to the contract be directed to pay into the common fund contemplated by the contract the sums represented by the promissory notes, and that the common fund so secured be distributed among the plaintiffs or those determined by the court to be entitled to participate therein.

The lower court sustained a demurrer to the complaint and the decision was affirmed in the District Court of Appeal. The Supreme Court, however, reversed the judgment. In addition to allowing liquidated damages it held $:^{98}$

"The complaint alleges the execution and delivery of the notes, demand for payment, failure and refusal to pay the same, and contains a prayer for judgment thereon; it, therefore, states a cause of action upon the notes. The complaint also sets forth

96 Supra, n. 93.

si (1920) 182 Cal. 588, 189 Pac. 445.

os Ibid., p. 595. 
the contract between the parties and asks the court, in the exercise of its equity jurisdiction, to distribute the money, after payment, among those to whom the court finds it should go under the contract. While the satisfaction of a legal demand is the basis of the action and there is, doubtless, a remedy at law by an action upon the notes, the steps necessary to a final and complete adjustment of the rights of the parties include the collection, by the officer designated by the contract, of various sums of money from a number of persons and the disbursement thereof after the respective rights of the several parties in and to the common fund have been determined. The relief, if it is to be effective and complete, may thus involve and include an adjudication of the obligations and duties imposed upon this officer by the contract, as well as an accounting among the parties to the contract. The grounds for the jurisdiction of equity in this case are further strengthened by the fact that a multiplicity of suits would be required if a purely legal remedy were sought, whereas the rights of the parties can be more readily determined in a single action."

The problems involved in considering the remedial side of liquidated damages are relatively simple, but the question of pleading, which should be the least important part of the entire subject, appears to have presented a good many difficulties.

In considering the subject of pleading we shall first consider the substance of the complaint and then the question of actual damages.

\section{PLEADING}

\section{Substance of the Complaint}

It has been repeatedly held by the California courts that it is necessary to show both by averment and proof that the case comes within the exception of section 1671 of the Civil Code, as otherwise there would be a presumption that the agreement falls within section 1670 of the Code and is therefore void.99

Without an averment to this effect. evidence cannot be offered on the subject ${ }^{200}$ and a finding that in the nature of the case it will be impracticable or extremely difficult to fix actual damages will

${ }^{99}$ Long Beach v. Dodge (1902) 135 Cal. 401, 67 Pac. 499; Dyer Bros. Golden West. Iron Iron Works v. Central Iron Works (1920) 182 Cal. 588. 189 Pac. 445; Los Angeles Olive Growers Association v. Pacific S. Co. (1914) 24 Cal. App 95, 99, 140 Pac. 295; Thomas v. Anthony (1916) 30 Cal. App. 217, 220, 157 Pac. 823; Rez v. Suminers (1917) 34 Cal. App. 527, 529168 Pac. 156; McInerney v. Mack (1917) 34 Cal. App. 153, 156, 166 Pac. 867.

ino Long Beaclı v. Dodge. supra, n. 99. 
be held unsupported by the evidence. ${ }^{101}$ Where it does not appear in the record that it was impracticable or extremely difficult to fix actual damages, judgment for liquidated damages must be reversed. ${ }^{102}$ A mere stipulation for liquidated damages in the bond itself will not cure the defect. ${ }^{103}$ The burden of proof is upon the person maintaining the validity of the liquidated damages clause to show that it is valid, and if no evidence at all is offered as to the ease or difficulty of ascertaining actual damages, the stipulated damage will be held a penalty. ${ }^{104}$

An exception to these rules, however, has been established by the California courts in two classes of contracts. In contracts involving the sale of good will of an established business with an agreement to pay liquidated damages in case of breach of the agreement not to engage in a similar line of business, actual damages are considered so absolutely uncertain of ascertainment that the plaintiff need prove only the breach of the contract in order to recover the stipulated damages. It is not necessary either to allege or to prove the impracticability of fixing damages-an allegation of the due execution of the contract and of the breach is all that is necessary. ${ }^{105}$

The second exception to the rule occurs in the case of contracts for digging oil-wells on a royalty basis. Of such agreements, the Supreme Court has said: $:^{106}$

"Damages for breach of contracts touching future interests in oil-wells of unknown value are of such remote and speculative character as to place them peculiarly within the rule that the parties should have the right to fix them by mutual agreement."

The agreement itself, as in the sale of good will of a business, shows that the nature of the case is such as to bring it within section 1671 of the Civil Code so that liquidated damages are proper without further pleading or proof. ${ }^{10 \tau}$

101 Rez v. Summers (1917) 34 Cal. App. 527, 528, 168 Pac. 156.

102 Escondido Oil Co. v. Glasser, supra, n. 92; McComber v. Kellerman (1912) 162 Cal. 749, 752, 124 Pac. 431; Allen v. Narver, supra, n. 92.

${ }_{103}$ Allen v. Narver, supra, n. 92 ; Long Beach v. Dodge, supra n. 99, at p. 405 .

${ }_{10}+$ Green v. Frahm (1917) 176 Cal. 259, 262, 168 Pac. 114. Los Angeles v. Shafer (1921) 35 Cal. App. Dec. 605, 609.

105 Shafer v. Sloan (1906) 3 Cal. App. 335, 338, 85 Pac. 162; Potter v. Ahrens (1896) 110 Cal. 674, 680, 43 Pac. 388. See supra, n. 55 for other cases involving the sale of the good will of a business.

106 Escondido Oil Co. v. Glaser (1909) 144 Cal. 494, 500, 77 Pac. 1040; Allen v. Narver (1918) 178 Cal. 202, 204, 172 Pac. 980.

107 Escondido Oil Co. v. Glaser, supra, n. 106; McComber v. Kellerman

(1912) 162 Cal. 749, 752, 124 Pac. 431; Allen v. Narver, supra, n. 106. 
These exceptions, however, have been applied only to these two classes of cases. The California courts have refused to apply it to rent cases $^{108}$ and it remains to be seen whether the exception will be further extended or restricted.

In general, therefore, facts should be alleged to bring the case within the statute, but an allegation that it is impracticable or extremely difficult to $f x$ actual damages is sufficient. This is the ultimate fact. Whether the proof will sustain the allegation is another matter, but as against demurrer a cause of action is stated. ${ }^{109}$

While it is sufficient to follow the wording of the Code and to plead nothing more, it is also permissible to go more into detail and to plead the particular facts which show the impracticability of determining actual damages. ${ }^{10}$ It is not sufficient to allege that it was understood between the parties at the time of making the contract that it was impracticable or extremely difficult to fix actual damage. The allegation should refer to the impracticability or difficulty as a matter of fact and not as a matter of understanding of the parties. ${ }^{111}$

Furthermore, the exact wording of the Code should be followed. An allegation that it was extremely difficult, if not impossible, to estimate actual damages amounts to nothing in its alternative form and is merely an allegation that it is extremely difficult to estimate actual damage. A finding upon such an allegation that damages could have been ascertained and that it is untrue that the same could not be ascertained. is not responsive to the pleadings and is improper. ${ }^{112}$

\section{Actual Damagres ${ }^{113}$}

In case stipulated damages, as provided in the contract. are

\footnotetext{
${ }^{108}$ Rez v. Summers (1917) 34 Cal. App. 527, 528. 168 Pac. 156; Semlle' Green v. Frahm (1917) 176 Cal. 259, 262, 168 Pac. 114.

109 Dyer Bros. v. Central Iron Works (1920) 182 Cal. 588; 189 Pac. 445; Los Angeles Etc. Association v. Pacific Surety Co. (1914) 24 Cal. App. 95, 99, 140 Pac, 295.

110 This was done in Stark v. Shemada (1921) 34 Cal. App. Dec. 867. It might be difficult to draw the line between ultimate and cvidentiary facts in case such a method of pleading be adopted, but $\$ 41 / 2$, Art. VI of the Cal. Const. would thoroughly protect the pleader.

111 Pacific Factor Co. v. Adler (1891) 90 Cal, 110, 120, 27 Pac. 36, 25 Am. St. Rep. 102.

112 Consolidated Lumber Co. v. Los Angcles (1917) 33 Cal. App. 698, 700. 166 Pac. 385.

113 An action for liquidated damages may be joined with an action for actual damages. Lightner v. Menzcl (1868) 35 Cal. 452 . In this case
} 
void as being a penalty, the rest of the contract is not affected and actual damages may be recovered ${ }^{114}$ but they must be pleaded and proved. $^{115}$ In such a situation, the actual damages recovered are not limited to the amount of the stipulated damages, ${ }^{116}$ although there is an early dictum which appears to suggest a contrary rule. ${ }^{117}$

\section{PROOF}

\section{LAW OR FACT}

Shall the judge or the jury determine whether it is impracticable or extremely difficult to fix actual damages? The question has not yet arisen in California, although on various occasions the courts have considered whether the question involved is one of law or fact. For the most part it has been held a question of fact, ${ }^{118}$ although on two occasions the District Court of Appeal of the Second Appellate District has called it a matter of law. ${ }^{120}$

In Dyer Brothers v. Central Iron Works ${ }^{20}$ the Supreme Court declared the question to be "largely a question of fact" and held that an allegation of the complaint stating "that at all times it was and is impracticable and extremely difficult to fix actual damages or loss to plaintiffs or to prove the same" renders the complaint sufficient for the purpose of bringing the case within the exception

defendant demurred because an action for liquidated damages was joined with an action for debt (p. 455). The action of the trial court in overruling the demurrer was sustained (p. 459). Evidence of either actual damages or of the impracticability of determining such damages is admissible Tatsuno v. Pedersen (1913) 21 Cal. App. 585, 587, 132 Pac. 608.

114 Los Angeles Olive Growers Association v. Pacific Surety Co. (1914) 24 Cal. App. 95, 99, 140 Pac. 295; Tatsuno v. Pedersen (1913) 21 Cal. App. 585, 587, $132 \mathrm{Pac}$. 608. A complaint that fails to state a cause of action for liquidated damages may still state a cause of action for actual damages. If the complaint shows the making of the contract, the breach and a sufficient allegation of damages, a cause of action is stated. The liquidated damage pleading is mere surplusage. Los Angeles Olive Growers Association v. Pacific Surety Co. (1914) 24 Cal. App. 95, 99, 140 Pac. 295. ${ }_{115}$ Muldoon v. Lynch (1885) 66 Cal. 536, 6 Pac. 417; Nakagawa v. Okamoto (1913) 164 Cal. 718, 724, 130 Pac. 707.

116 Sherman v. Gray (1909) 11 Cal. App. 348, 352, 104 Pac. 1004.

217 People v. Central Pacific Ry. Co. (1888) 76 Cal. 29, 38, 18 Pac. 90. 118 Dyer Bros. v. Central Iron Works (1920) 182 Cal. 588, 189 Pac. 455; Stark v. Shemada (1921) 34 Cal. App. Dec. 867, 869 ; Consolidated Lumber Co. v. City of Los Angeles (1917) 33 Cal. App. 698, 699, 166 Pac. 385; Pacific Factor Co. v. Adler (1891) 90 Cal. 110, 120, 27 Pac. 36, 25 Am. St. Rep. 102. Los Angeles v. Shafer (1921) 35 Cal. App. Dec. 605.

118 Thomas v. Anthony (1916) $30 \mathrm{Cal}$. App. 217, 221, $157 \mathrm{Pac}$ 823; McInerney v. Mack (1917) 34 Cal. App. 153, 166 Pac. 867. 120 (1920) .182 Cal. 588, 593, 189 Pac. 445. 
provided for by section 1671 of the Civil Code.121 If the allegation in question were a conclusion of law, its truth would not be admitted by the demurrer and a cause of action would not have been stated.

In Stark v. Shemada ${ }^{122}$ the lower court found that it was impracticable and extremely difficult to fix the actual damages. Appeal was taken upon the judgment roll alone and the judgment was affirmed by the District Court of Appeal, which declared that it is "always a question of fact" whether or not it would be impracticable or extremely difficult to fix actual damages, so that the findings on that question would be conclusive upon appeal on the judgment roll alone.

The same view of the subject is found in dicta in other California cases. ${ }^{123}$

Irreconcilably opposed to these cases are two decisions of the District Court of Appeal holding the matter to be one of law. ${ }^{124}$ Both rely upon a dictum in a Montana decision ${ }^{125}$ as their authority and the Montana Court cites no authority for its statement. Neither of them refers to the cases which consider it as a question of fact and with one exception the reverse is likewise true. This exception is in the case of Los Angeles v. Shafer. ${ }^{126}$ The opinion of the presiding judge pro tem in this case held the question to be one of fact and not one of law, but he cites among other authorities for his holding the two California cases which adopted the opposite view. ${ }^{127}$

It is to be noted, however, that while the question has been referred to by some of the California Courts as a "question of fact" ${ }^{128}$ or "always a question of fact" ${ }^{129}$ yet the Supreme Court

121 Goldstein v. Healy (1921) 34 Cal. App. Dec. 731, 733; Branham v. Mayor (1864) 24 Cal. 585, 602.

122 (1921) 34 Cal. App. Dec. 867.

123 Consolidated Lumber Co. v. City of Los Angcles, supra, n. 118; Dyer Bros. v. Central Iron Works, supra, n. 118; Stark v. Shemada, supra, n. 118; Pacific Factor Co. v. Adler, supra, n. 118.

${ }_{124}$ Thomas v. Anthony (1916) 30 Cal. App. 217, 221. 157 Pac. 823; McInerney v. Mack (1917) 34 Cal. App. 153, 157, 166 Pac. 867.

125 Deuninck v. West Gallantin Inv. Co. (1903) 28 Mont. 262, 72 Pac. 618. 128 (1921) 35 Cal. App. Dec. 605.

127 The majority of the court concurred in the result he reached but did not discuss this phase of the subject.

128 Consolidated Lumber Co. v. City of Los Angeles (1917) 33 Cal. App. 698, 699, 166 Pac. 385; Pacific Factor Co. v. Adler (1891) 90 Cal. 100, 120, 27 Pac. 36, 25 Am. St. Rep. 102.

${ }^{129}$ Stark v. Shemada (1921) 34 Cal. App. Dec. 867, 869. 
in its most recent opinion" 130 on the subject spoke of it as "largely a question of fact." Whether the use of the expression "largely a question of fact" instead of the expression "always a question of fact" has any significance remains for the Supreme Court to say.

As far as the functions of judge and jury are concerned, the question would appear to be rather a mixed case of law and fact, rather than always a question of fact. Would it be the proper function of a jury to decide whether, from the nature of the case, it is impracticable or extremely difficult to fix actual damages, or is it enough that the jury find the truth of the evidence to support the ultimate fact? Should not the court consider the facts as found by the jury and in view of these facts itself decide the impracticability or difficulty of determining the actual damages? This division of the question gives full significance to the word "largely" as used by the court in the Dyer case in its expression "largely a question of fact," but until the Supreme Court has decided the matter it will still be a moot question in California.

\section{CONCLUSION}

Although the remedy of liquidated damages is an exception and not the rule, it is playing a more important part each year in the mercantile world. The action of the California courts in recognizing liquidated damages in farmers' co-operative marketing corporation contracts ${ }^{132}$ and in collective bargaining associations of employers of labor $^{132}$ has opened a vast field to the remedy. The Dyer case ${ }^{133}$ has cleared up the situation considerably, not only on the procedural side ${ }^{134}$ but in the field of substantive law as well. ${ }^{135}$ A lawyer who draws a liquidated damages clause now treads on well-settled ground and no longer gropes in the dark. It is now as simple to plead a cause of action for

130 Dyer Bros. v. Central Iron Works (1920) 182 Cal. 588, 189 Pac. 445. 131 Anaheim Citrus Fruit Assn. v. Yeoman (1921) 34 Cal. App. Dec. 798, 197 Pac. 959. Petition to have cause heard and determined in Supreme Court denied May 16, 1921.

${ }_{132}$ Dyer Bros. v, Central Iron Works (1920) 182 Cal. 588, 189 Pac. 445. 133 Supra, n. 132.

$134 \mathrm{By}$ holding that an allegation that it is impracticable or extremely difficult to fix actual damages is sufficient to bring the case within $\S 1671$ Civil Code.

135 By emphasizing the reasonableness of the stipulated sum in determining intent. For the discussion see supra, p. 14. 
liquidated damages as an action upon a common count,, ${ }^{136}$ while no difficulty should be encountered in the drawing up of the agreement itself. ${ }^{137}$ Far too many cases in the past have been decided upon mere procedural points and if this paper does no more than to point out the pitfalls that await one who strays too far from the broad path of liquidated damages it has served its purpose.

Stockton, California.

Stanley M. Arndt.

${ }^{136}$ By merely pleading that it is impracticable or extremely difficult to fix actual damages.

${ }^{137}$ See supra, p. 22. 